\title{
ANALISIS SIKLON TROPIS NOCK-TEN BERBASIS DATA SATELIT HIMAWARI
}

\author{
Prayoga Ismail*, Nizar Manarul Hidayat, Ejha Larasati Siadari \\ Sekolah Tinggi Meteorologi Klimatologi dan Geofisika, Tangerang Selatan \\ "Email: yogamailforalvin@gmail.com
}

\begin{abstract}
ABSTRAK
Siklon tropis Nock-Ten yang melintasi Filipina pada 25-26 Desember 2016 termasuk dalam kategori super taifun. Dalam skala meteorologi, siklon tropis termasuk dalam fenomena berskala sinoptik. Dampak yang ditimbulkan dapat memengaruhi kondisi atmosfer di wilayah Indonesia, terutama siklon tropis yang terbentuk di perairan Samudera Pasifik Barat Daya dan Samudera Hindia sebelah utara Australia. Oleh karena itu, perlu dilakukan pemantauan aktivitasnya karena berpengaruh pada dinamika atmosfer yang memicu angin kencang dan tumbuhnya awan hujan. Penelitian ini bertujuan untuk menganalisis pertumbuhan, pergerakan, danintensitas Taifun Nock-Ten dengan menggunakan data satelit Himawari 8 kanal IR1. Metode yang digunakan berupa analisis indeks konvektif dengan menggunakan data TBB (Temperature of black body) sebagai suhu puncak awan dan metode pengamatan visual berbasis teknik Dvorak untuk memantau pertumbuhan dan pergerakan siklon, dan untuk mendapatkan T-Number yang dapat digunakan untuk memprakirakan intensitasnya berupa kecepatan angin maksimum dan tekanan minimum pusat siklon. Berdasarkan analisis suhu puncak awan dari siklon tropis Nock-Ten didapatkan nilai indeks konvektif yang tinggi yaitu berkisar dari 49.9 hingga 74.4. Siklon tropis Nock-Ten memiliki masa hidup 8 hari, terbentuk di Samudera Pasifik sebelah utara Papua berupa MCS (Mesoscale Convective System) pada 20 Desember 2016 yang berpropagasi ke barat dan punah pada 28 Desember 2016. Intensitas maksimum terjadi pada 25 Desember 2016 pukul 00.00 UTC dengan T-Number mencapai 7.0 dengan nilai prakiraan kecepatan angin maksimum mencapai 140 knots dan tekanan udara minimum mencapai 898 hPa, setara dengan siklon tropis kategori 5 skala Saffir-Simpson.
\end{abstract}

Kata kunci: siklon tropis, satelit himawari, indeks konvektif, teknik dvorak.

\begin{abstract}
Nock-Ten tropical cyclone across the Philippines on 25-26 December 2016 was categorized as the super typhoon. In meteorological scale, tropical cyclone is included in the synoptic-scale phenomena. The impact could affect atmospheric conditions in Indonesian region, especially for tropical cyclones that formed in the Southwestern Pacific Ocean and the Indian Ocean north of Australia. Therefore, there should be monitoring the activities because it affects the dynamics of the atmosphere triggering the strong winds and rain clouds.This study aimed to analyze the growth, movement, and intensity of Typhoon Nock-Ten by using infrared channel of Himawari 8 satellite data. The methods used in the paper are convective index analysis by using TBB data (Temperature of the black body) as the temperature of the cloud tops and visual observation method based on Dvorak technique to monitor the development and movement of the cyclone, and to determine T-Number that can be used to predict the intensity in the form of maximum wind speed and minimum pressure of the cyclone. Based on the analysis of the temperature of the cloud tops of the Nock-Ten tropical cyclone obtained high convective index values ranged from 49.9 to 74.4. Nock-Ten tropical cyclones have a life span of 8 days, formed in the Pacific Ocean north of Papua in the form of MCS (Mesoscale Convective System) on 20 December 2016, propagating westward and dissipated on 28 December 2016. The maximum intensity occurred on 25 December 2016 at 00.00 UTC with T-Number reached 7.0 with the estimated maximum winds of 140 knots and a minimum air pressure reached $898 \mathrm{hPa}$, equivalent to a category 5 tropical cyclone on the Saffir-Simpson scale.
\end{abstract}

Keywords: tropical cyclone, himawari satellite, convection index, dvorak technique. 


\section{PENDAHUluaN}

Daerah tropis merupakan daerah di permukaan bumi yang secara astronomis berada di sekitar ekuator yang dibatasi oleh garis lintang $23.5^{\circ} \mathrm{LS}$ dan 23.5 ${ }^{\circ} \mathrm{LU}$. Daerah tropis merupakan wilayah yang lebih intensif dalam menerima radiasi matahari dibandingkan dengan daerah lintang menengah, lintang tinggi, dan daerah kutub karena sudut datang sinar matahari yang lebih besar di daerah lintang rendah. Hal ini menyebabkan suhu permukaan laut di daearah tropis lebih tinggi daripada daerah-daerah lainnya. Suhu permukaan laut yang tinggi kemudian dapat membentuk pusat tekanan rendah yang dapat memicu terjadinya siklon tropis yang dimulai dengan adanya gangguan tropis lalu depresi tropis, badai tropis, selanjutnya terjadi siklon tropis (Emanuel, 1988).

Menurut Emanuel (2003), siklon tropis merupakan badai yang berasal dari lautan tropis yang dipicu oleh perpindahan panas dari lautan. Siklon tropis terbentuk di atas lautan dengan suhu permukaan laut lebih dari $26^{\circ} \mathrm{C}$ dan jarang terbentuk pada lintang kurang dari $5^{\circ}$. Struktur siklon tropis meliputi mata, dinding mata, rainbands (kumpulan hujan), boundary layer inflow, upper tropospheric outflow. Siklon tropis memerlukan lautan tropis yang hangat dan lembab sehingga menyebabkan adanya pusat tekanan rendah yang berputar secara siklonik dengan gerak angin berlawanan dengan arah jarum jam pada Belahan Bumi Utara (BBU) dan searah jarum jam pada Belahan Bumi Selatan (BBS) serta menyebabkan massa udara berputar dan terangkat. Siklon tropis merupakan salah satu peristiwa meteorologi yang merusak dan dapat menghasilkan angin kencang yang membahayakan, storm surge yaitu gelombang yang besar yang dapat menghancurkan kehidupan di wilayah pesisir, hujan lebat, angin kencang, banjir, dan tanah longsor serta kerugian ekonomi yang besar dan mengancam jiwa. Indonesia merupakan daerah yang berada di daerah tropis dan termasuk wilayah ekuator (khatulistiwa), tepatnya pada $95^{\circ} \mathrm{BT}$ sampai $140^{\circ} \mathrm{BT}$ dan $6^{\circ} \mathrm{LU}$ sampai $11^{\circ} \mathrm{LS}$. Hal inilah yang menyebabkan hanya sebagian kecil dari wilayah Indonesia yang mungkin dapat mengalami kejadian siklon tropis dan kemungkinannya sangat kecil karena wilayah di sekitar ekuator memiliki gaya coriolis yang kecil padahal efek corilolis merupakan penggerak awal dari putaran siklon (Mustika, 2008). Sebagian besar siklon tropis (65\%) terjadi pada daerah lintang $10^{\circ}$ hingga $20^{\circ}$, dan sedikit sekali $( \pm 13 \%)$ yang muncul pada lintang di atas $22^{\circ}$, serta siklon tropis tidak akan muncul di wilayah $4^{\circ}$ dari ekuator (Tjasyono, 2000). Walaupun terbebas dari jejak siklon tropis, kondisi cuaca di beberapa daerah di Indonesia dipengaruhi siklon yang terbentuk di sekitar wilayah Indonesia terutama siklon tropis yang terbentuk di Samudera Hindia sebelah utara Australia dan Samudera Pasifik sebelah utara Papua, seperti yang dikaji pada penelitian ini yaitu siklon tropis Nock-Ten yang terbentuk di Samudera Pasifik Barat Daya sebelah utara perairan Biak. Dampak siklon tropis sebagai fenomena cuaca skala sinoptik dapat menjangkau hingga ribuan kilometer dari pusat badai dengan skala waktu sampai beberapa hari hingga mingguan. Sebagai contoh, cuaca ekstrem berupa hujan lebat dengan intensitas mencapai $102 \mathrm{~mm}$ dalam sehari di Biak pada Desember 2014 terjadi pada saat terbentuknya siklon tropis Hagupit yang menerjang Filipina (Ismail et. al, 2017).

Waktu kejadian siklon tropis dapat dipantau dengan bantuan satelit Himawari yang masuk dalam rangkaian Geostationary Meteorological Satellite (GMS) yang merekam gambar permukaan bumi setiap hari. Dari gambar satelit itu juga dapat diketahui durasi terjadinya siklon tropis (Tjasyono, 1999). Begitu juga dengan pusat siklon yang merupakan daerah yang bebas dari awan dengan kondisi peranginan yang relatif tenang dapat diamati secara visual melalui citra satelit GMS. Pergerakan siklon tropis (track) juga dapat dipantau dari citra satelit dan intensitasnya dengan menggunakan teknik Dvorak (Krismianto, 2015).

Tujuan dari penelitian ini adalah untuk mengetahui tahap-tahap pembentukan, pergerakan, dan intensitas siklon tropis menggunakan data satelit Himawari dari salah satu siklon tropis yang menerjang wilayah Filipina pada 25 Desember 2016, yaitu siklon tropis Nock-Ten yang dilaporkan mulai terbentuk pada 20 Desember 2016 dan mulai menghilang sebelum memasuki 28 Desember 2016. Ada beberapa penelitian yang menjadi pondasi pada studi siklon tropis, diantaranya adalah teknik Dvorak yang didapatkan dari hasil penelitian Dvorak (1975) dan dikembangkan oleh Dvorak (1984) tentang 
analisis intensitas siklon tropis berbasis data satelit dengan merumuskan T-Number.

Metode tersebut juga dikembangkan menjadi ADT (advanced dvorak technique) oleh Olander dkk.

(2007). Selain itu, ada pula studi lain untuk menentukan intensitas siklon tropis seperti halnya Liu dkk., 2015 yang menggunakan NDCI (normalized difference convection index) dengan turunan data satelit untuk observasi taifun.

\section{DATA DAN METODOLOGI}

Penelitian tentang analisis siklon tropis NockTen menggunakan data berupa data satelit Himawari kanal IR1 yang diperoleh dari basis data satelit Japan Meteorological Agency (JMA). Adalah data satelit Himawari 8 berupa DN (digital number) pada posisi pergerakan sistem siklon tropis Nock-Ten. Data tersebut diambil pada jam utama yaitu pukul 00.00, 06.00, 12.00, dan 18.00 UTC selama sembilan hari yaitu dari 20 - 28 Desember 2016. Selain itu, penelitian ini juga menggunakan data yang diperoleh dari basis data satelit Badan Meteorologi Klimatologi dan Geofisika

(BMKG). Data yang diunduh yaitu data satelit saat terjadinya siklon tropis Nock-Ten dari awal terbentuknya bibit siklon hingga punahnya siklon, masing-masing pada jam-jam utama yaitu 00.00, 06.00, 12.00, dan 18.00 UTC setiap harinya. Data satelit Himawari 8 memiliki resolusi waktu sepuluh menit dan resolusi ruang $0.5-2 \mathrm{~km}$ dengan cakupan wilayah dari 500LU - 150LS dan 900BT -1550BT.
Metode yang digunakan dalam penelitian ini adalah analisis indeks konvektif berdasarkan suhu puncak awan dari sistem siklon tropis Nock-Ten yang didapatkan dengan cara konversi file yang mengubah data satelit Himawari dalam bentuk DN (digital number) menjadi data temperature of black body (TBB) sebagai suhu puncak awan. Dengan langkah pengerjaannnya adalah sebagai berikut:

1. Data satelit Himawari 8 kanal IR1 berupa data yang berekstensi .pgm dan .dat dikonversi terlebih dahulu menjadi file yang berekstensi netCDF dengan menggunakan aplikasi statistik $R$.

2. Data netCDF digunakan untuk mencari suhu puncak awan $(\mathrm{TBB}=$ temperature of black body) dalam satuan Kelvin.

3. Identifikasi TBB dilakukan empat kali dalam sehari yaitu pada pukul 00, 06, 12, dan 18 UTC dari 20- 27 Desember 2016.

4. Output hasil running data netCDF dari aplikasi $R$ adalah data dalam format txt.

5. Data dalam format .txt selanjutnya diolah menjadi grafik yang berbentuk time series.

6. Plot hasil TBB di Microsoft Excel untuk memudahkan pembuatan grafik secara time series.

7. Data TBB digunakan untuk mencari nilai indeks konvektif menggunakan rumus $255 \mathrm{~K}$ - TBB. Threshold senilai 255 Kelvin tersebut diperoleh dari penelitian Murakhami pada tahun 1987 (Krismianto, 2015). 


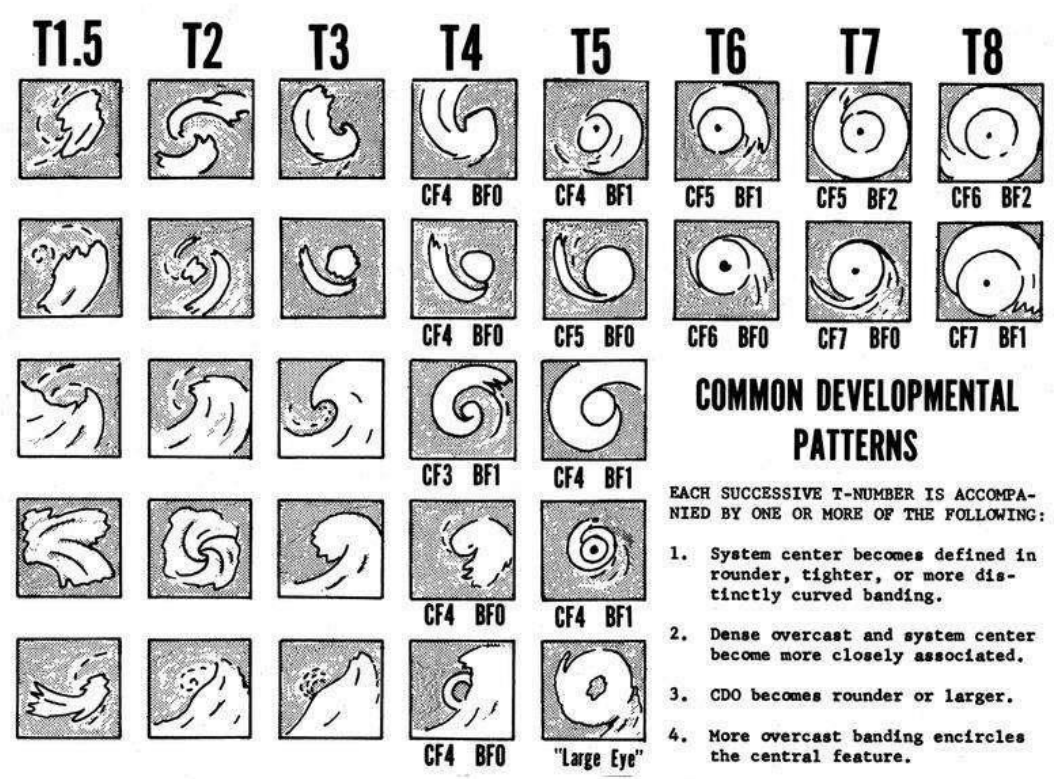

Gambar 1. Diagram Dvorak untuk menentukan T-Number (Sumber: https://en.wikipedia.org/wiki/Dvorak_technique)

Selain itu, penelitian ini juga menggunakan metode pengamatan visual berbasis teknik Dvorak untuk mendapatkan T-Number. Pengamatan visual menggunakan data satelit Himawari 8 dalam format Sataid yang diolah dengan aplikasi GMSLPD yang digunakan untuk memantau pertumbuhan dan pergerakan sistem siklon tropis Nock-Ten. Pengamatan visual pada citra satelit Himawari yang dihasilkan di GMSLPD kemudian dibandingkan dengan diagram Dvorak berupa pola-pola umum pada proses pertumbuhan dan perkembangan siklon tropis seperti yang tertera pada gambar $1 \mathrm{di}$ atas. Polapola primer yang digunakan antara lain yaitu pola curved band untuk T-Number $1.0-4.5$, pola shear untuk $T$ -
Number 1.5 - 3.5, pola CDO (central dense overcast) untuk T-Number 2.5 - 5.0, pola central cold cover, pola banding eye untuk $T$ Number 4.0 - 4.5, dan pola eye untuk $T$ Number 4.5 - 8.0. Dengan metode pengamatan visual tersebut dapat teridentifikasi Dvorak $T$ Number. Nilai T-Number berkisar dari 1.0 - 8.0 dimana setiap nilainya dapat memprakirakan kekuatan angin maksimum dan tekanan udara di pusat siklon seperti yang ditunjukkan pada tabel 1 di bawah ini. Dari tabel tersebut terlihat bahwa, setiap angka T-Number dapat digunakan untuk memprakirakan kecepatan angin maksimum, tekanan udara terendah, bahkan ekuivalensinya dengan kategori siklon tropis dalam skala Saffir-simpson.

Tabel 1. Dvorak T-Number dan hubungannya dengan kecepatan angin dan pusat tekanan rendah siklon tropis (Sumber: https://en.wikipedia.org/wiki/Dvorak technique). 


\begin{tabular}{|c|c|c|c|c|c|c|}
\hline \multirow{2}{*}{ T-Number } & \multicolumn{3}{|c|}{ 1-min Winds } & \multirow{2}{*}{$\begin{array}{c}\text { Category } \\
\text { (SsHWws) }\end{array}$} & \multicolumn{2}{|c|}{$\begin{array}{l}\text { Min. Pressure } \\
\text { (millibars) }\end{array}$} \\
\hline & (knots) & (mph) & $(\mathrm{km} / \mathrm{h})$ & & Atlantic & $\begin{array}{l}\text { NW } \\
\text { Pacific }\end{array}$ \\
\hline $1.0-1.5$ & 25 & 29 & 46 & TD & - & $\cdots$ \\
\hline 2.0 & 30 & 35 & 56 & $\mathrm{TD}$ & 1009 & 1000 \\
\hline 2.5 & 35 & 40 & 65 & TS & 1005 & 997 \\
\hline 3.0 & 45 & 52 & 83 & TS & 1000 & 991 \\
\hline 3.5 & 55 & 63 & 102 & TS & 994 & 984 \\
\hline 4.0 & 65 & 75 & 120 & Cat 1 & 987 & 976 \\
\hline 4.5 & 77 & 89 & 143 & Cat $1-2$ & 979 & 966 \\
\hline 5.0 & 90 & 104 & 167 & Cat $2-3$ & 970 & 954 \\
\hline 5.5 & 102 & 117 & 189 & Cat 3 & 960 & 941 \\
\hline 6.0 & 115 & 132 & 213 & Cat 4 & 948 & 927 \\
\hline 6.5 & 127 & 146 & 235 & Cat 4 & 935 & 914 \\
\hline 7.0 & 140 & 161 & 260 & Cat 5 & 921 & 898 \\
\hline 7.5 & 155 & 178 & 287 & Cat 5 & 906 & 879 \\
\hline 8.0 & 170 & 196 & 315 & Cat 5 & 890 & 858 \\
\hline $8.5 \dagger$ & 185 & 213 & 343 & Cat 5 & 873 & 841 \\
\hline
\end{tabular}

\section{HASIL DAN PEMBAHASAN}

\subsection{Analisis Indeks Konvektif}

Analisis indeks konvektif dimaksudkan untuk mengidentifikasi arus konveksi yang terjadi pada sistem siklon tropis. Apabila nilai indeks konvektif semakin besar (positif), maka di dalam suatu sistem konvektif tersebut terjadi arus konveksi yang sangat kuat sehingga keadaan atmosfer menjadi sangat tidak stabil dan memungkinkan untuk terbentuk sistem konvektif skala besar yang terorganisir, salah satunya adalah siklon tropis. Indeks konvektif dihitung dari selisih antara $255 \mathrm{~K}-\mathrm{TBB}$ (temperature of black body), dalam hal ini TBB adalah suhu puncak awan dalam satuan Kelvin. Hasil plotting data indeks konvektif dari tanggal 20 - 27 Desember 2016 yang tertera pada gambar 2 menunjukkan bahwa terdapat sistem konveksi yang sangat kuat di area terjadinya siklon tropis Nock-Ten dengan nilai indeks di atas 50. Nilai indeks konvektif di dalam sistem siklon Tropis Nock-Ten berkisar antara 49.9 hingga 74.4. Hal tersebut mengindikasikan bahwa adanya arus konveksi yang kuat dan dalam (deep convection) sehingga mampu menghasilkan sistem awan konvektif yang besar dan menjulang. Pada awal pembentukan bibit siklon yang berupa MCS (mesoscale convective system), indeks konvektif bernilai 64.9 merupakan angka yang sangat tinggi sehingga sangat potensial untuk dapat membentuk suatu sistem konvektif skala besar. Dalam perjalanannya, indeks konvektif mengalami peningkatan dan penurunan seiring perkembangan sistem dari depresi tropis menjadi badai tropis, dan akhirnya menjadi siklon tropis atau disebut sebagai taifun dan sebaliknya.

Pada gambar 2 juga menunjukkan distribusi indeks konvektif dari awal pembentukan siklon, proses intensifikasi, tahap matang, hingga masa peluruhan siklon. Area siklon yang berwarna putih terang dapat teridentifikasi sebagai daerah yang memiliki indeks konvektif paling tinggi dibandingkan area sekitarnya. Pada area inilah terjadi aktivitas konveksi yang sangat kuat. Warna yang semakin terang mengindikasikan aktivitas konveksi yang menguat, sedangkan 
warna yang semakin gelap mengindikasikan aktivitas konveksi yang melemah. Pada tahap awal pembentukan siklon, area putih terang masih kecil yang menunjukkan bahwa aktivitas konveksi masih tersebar dalam suatu sistem konvektif skala meso (MCS) dalam sebuah kluster awan dalam jarak $0-700 \mathrm{~km}$ seperti yang disebutkan pada penelitian Gray (1998). Tahap awal ini berlangsung dari tanggal 20 21 Desember 2016.

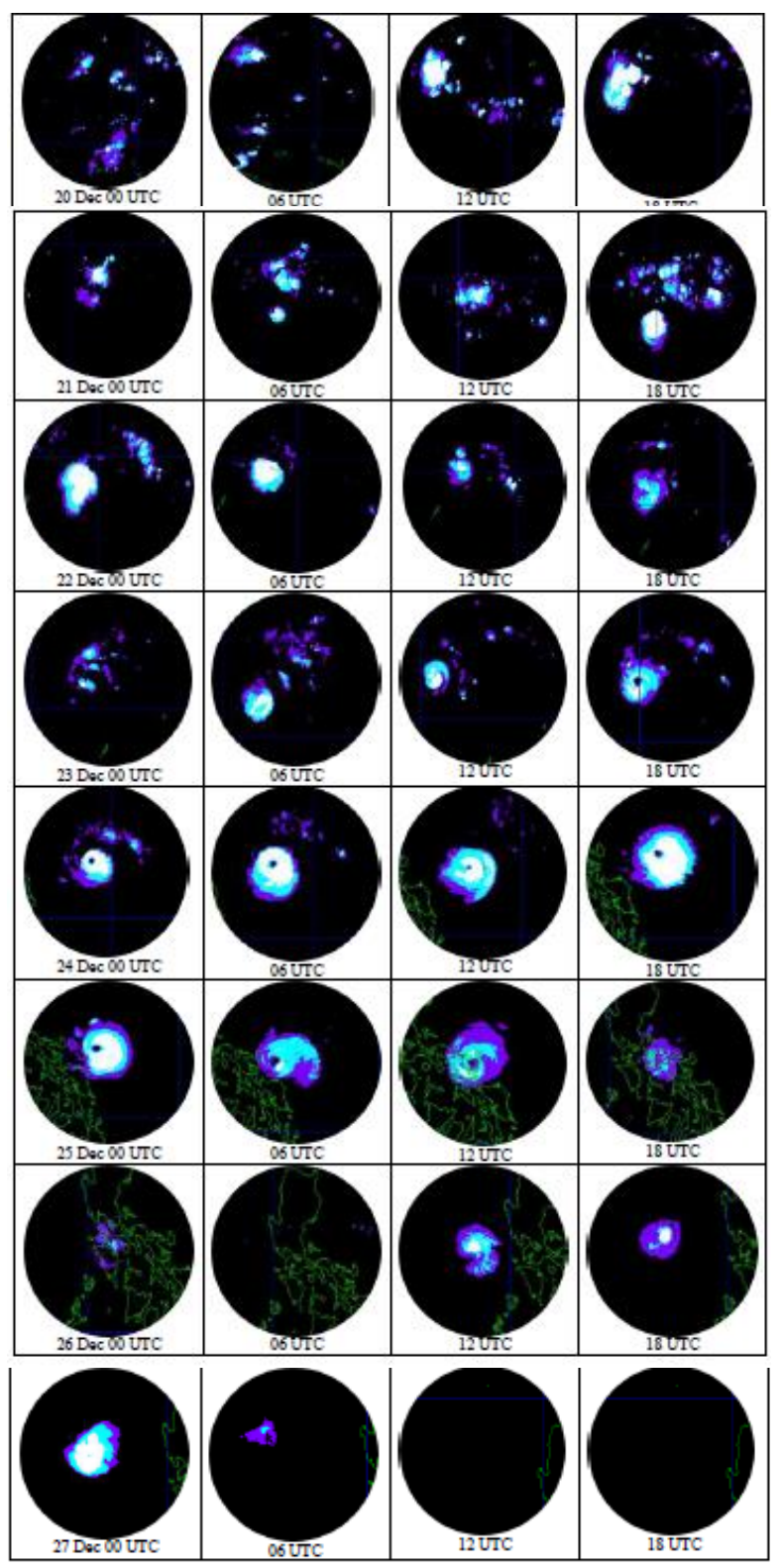

Gambar 2. Indeks konvektif siklon tropis Nock-Ten

Namun, dalam pada tahap selanjutnya yaitu proses intensifikasi yang dimulai dari tanggal 22 Desember 2016 dimana area putih terang mulai meluas yang menunjukkan bahwa aktivitas konveksi semakin menguat dan semakin luas hingga membentuk sebuah siklon tropis yang memiliki mata badai yang dikelilingi oleh dinding siklon dengan area putih terang. Pada tahap matang yang dimulai dari tanggal 24 Desember 2016 sudah terbentuk siklon dengan mata badai yang dikelilingi oleh dinding mata dengan area putih terang yang makin luas. Inilah puncak aktivitas konveksi siklon tropis Nock-Ten yang diindikasikan oleh indeks konvektif yang sangat tinggi. Pada tahap peluruhan siklon yang dimulai setelah melintasi daratan Filipina yaitu tanggal 26 Desember 2016, area putih terang berangsur-angsur menghilang dan diikuti juga dengan area warna biru dan ungu yang juga berangsur angsur menghilang, hal tersebut mengindikasikan bahwa terjadi penurunan aktivitas konveksi yang dapat diamati dari indeks konvektifnya.

Kemudian, ketika memasuki wilayah perairan hangat lagi, terjadi penguatan kembali aktivitas konveksi ditandai dengan munculnya area putih terang. Namun, pada akhirnya sebelum tanggal 28 Desember 2016 indeks konvektif terus menurun dan mulai tidak terlihat, sehingga hal tersebut menjadi indikator bahwa siklon tropis Nock-Ten telah punah.

\subsection{Analisis Teknik Dvorak}

Analisis teknik Dvorak dilakukan untuk memprakirakan intensitas siklon tropis berupa laju angin maksimum dan tekanan udara minimum di atas permukaan laut dengan menggunakan Tabel Dvorak T-Number (Tabel 1) di atas. Untuk menentukan nilai Dvorak $T$ Number dilakukan dengan cara teknik pengamatan visual dengan membandingkan citra satelit Himawari IR1 yang diolah pada GMSLPD seperti tertera pada gambar 3, dengan diagram Dvorak seperti yang tertera pada gambar 1. Berdasarkan pada Gambar 3 yang telah dilakukan teknik pengamatan visual Dvorak melalui dibandingkan dengan diagram Dvorak, maka dapat diketahui bahwa pada 20 Desember 2016 pukul 00.00 UTC sampai 21 Desember pukul 06.00 UTC, terlihat pusat tekanan rendah yang ditandai dengan aktivitas konvektif yang sangat tinggi, namun sistemnya masih tersebar dan belum terorganisir sebagai klaster awan MCS (mesoscale convective system) yang berjarak masing-masing sekitar $700 \mathrm{~km}$, inilah tahap awal munculnya bibit siklon tropis yang disebut TD (tropical depression) dengan Tnumber berkisar 1.5 - 2.0.

Dari angka tersebut diprakirakan laju angin maksimum sebesar 25 - 30 knots dengan 
tekanan udara berkisar di atas 1000 hingga $1000 \mathrm{hPa}$, sehingga tahap ini ekuivalen dengan TD pada skala Saffir-Simpson.

Kemudian pada pukul 12.00 UTC mulai terbentuk bibit siklon dalam bentuk klaster awan yang mulai menyatu membentuk sebuah sirkulasi siklonik $($ T-Number $=2.5)$ dan terus berkembang secara bertahap hingga T-Number $=3.5$ pada 23 Desember 2016 pukul 00.00 UTC yang setara dengan TS (tropical storm) pada skala Saffir-Simpson dengan laju angin maksimum 35 - 55 knots dan tekanan udara minimum 997 - $984 \mathrm{hPa}$. Badai tropis NockTen terlihat terus tumbuh menjadi siklon remaja $(T$-Number $=4.0)$ pada tanggal 23 Desember 2016 mulai pukul 06.00 UTC sampai 23 Desember 2016 pukul 12.00 UTC (T-Number $=$ 4.5) dan mulai berbentuk sebuah sirkulasi siklonik yang tertutup dan terorganisir hingga matang sebagai siklon tropis kategori 1-2 dengan laju angin maksimum $65-77$ knots dan tekanan udara minimum 976 - $966 \mathrm{hPa}$.

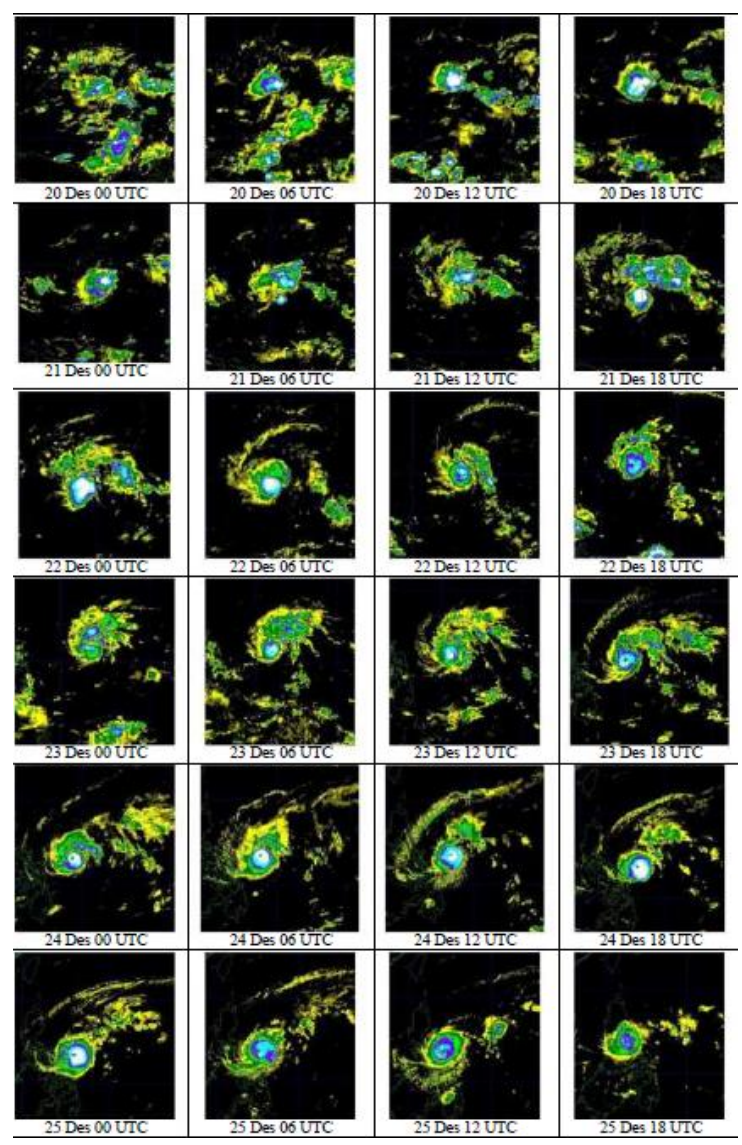

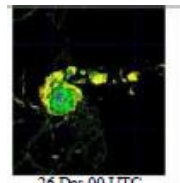
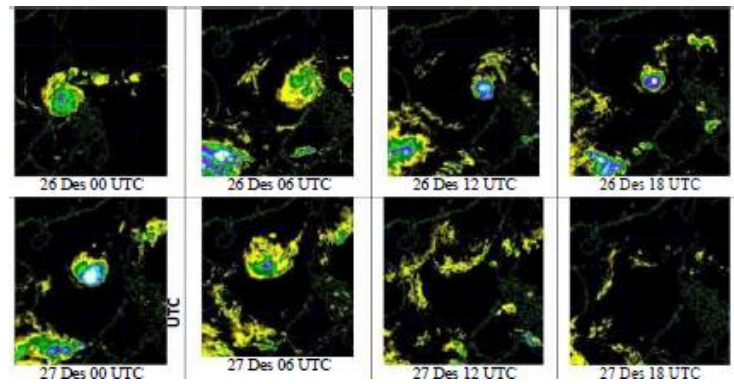

Gambar 3. Tahapan pertumbuhan siklon tropis Nock-Ten secara time series.

Siklon tropis Nock-Ten terus tumbuh hingga mulai menjadi dewasa dengan ditandai munculnya mata siklon $(T$ - Number $=5.0)$ pada pukul 18.00 UTC dan masih terus berkembang hingga mencapai puncaknya pada 25 Desember 2016 pukul 00.00 UTC $($ T-Number $=7.0)$, pada tahap ini setara dengan TC (tropical cyclone) kategori 5 pada skala Saffir-Simpson dengan fitur kecepatan angin maksimum hingga 140 knots dan tekanan udara di pusat siklon mencapai $898 \mathrm{hPa}$. Siklon tropis Nock-Ten terlihat mulai melemah pada 27 Desember 2016 pukul 06.00 UTC dan pada 27 Desember 2016 pukul 18.00 terlihat mulai lenyap. Siklon tropis Nock-Ten pun lenyap pada 28 Desember 2016 di perairan Laut Cina Selatan yang panas latennya rendah karena bersuhu dingin sehingga tidak ada lagi sumber tenaga. Siklon tropis Nock-Ten pun lenyap pada 28 Desember 2016 ditandai dengan Tnumber $=1.0$ yang mengindikasikan potensi konveksi yang sangat rendah karena sudah menurun drastis.

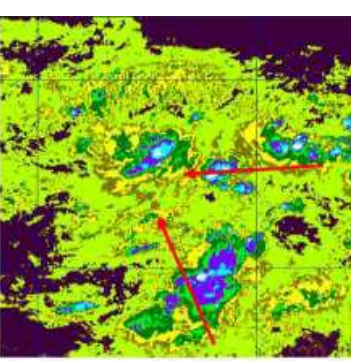

(a)

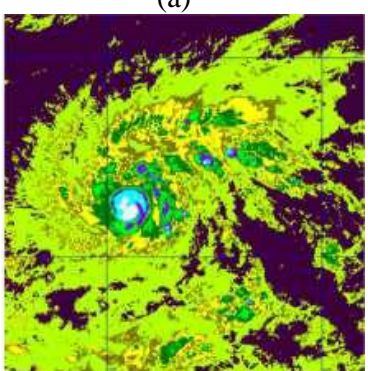

(c)

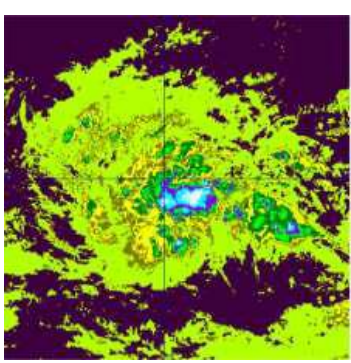

(b)

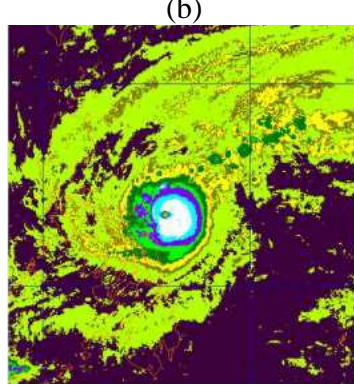

(d)
Gambar 4. Tahapan pembentukan TC dimana : a) Tahap awal pembentukan bibit siklon (TD) berupa 
gugusan awan MCS yang masing-masing berjarak maksimum sekitar $700 \mathrm{~km}$, di sekitar area bertekanan rendah tropis (Low), b) Tahapan awal TC, c) Tahapan Remaja TC, d) Tahap matang siklon tropis ditandai adanya mata badai.

Tahap-tahap utama pembentukan siklon tropis Nock-Ten tertera pada gambar 4a - 4d. Selanjutnya, untuk memprediksi intensitas siklon tropis Nock-Ten digunakan tabel Dvorak T-Number. Dari Tabel 2 dapat diketahui bahwa siklon tropis Nock-Ten pernah mencapai kategori 5 skala Saffir-Simpson dengan prakiraan nilai tekanan di pusat siklonnya mencapai $898 \mathrm{mb}$ dan prakiraan nilai laju anginnya mencapai 140 knots pada 25 Desember 2016 pukul 00.00 UTC.

Tabel 2. Hasil analisis T-Number siklon tropis Nock-Ten.

\begin{tabular}{|c|c|c|c|c|c|}
\hline Tanggal & Jam (UTC) & T-Number & $\begin{array}{l}\text { Skala Saffir- } \\
\text { Simpson }\end{array}$ & $\begin{array}{c}\text { Angin maks } \\
\text { (lnots) }\end{array}$ & $\begin{array}{l}\text { Tekanan udara } \\
(\mathrm{hPa})\end{array}$ \\
\hline \multirow[t]{4}{*}{$20 / 12 / 2016$} & 0 & 1.5 & TD & 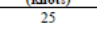 & $\begin{array}{l}3000 \\
>100\end{array}$ \\
\hline & 6 & 1.5 & TD & 25 & $>1000$ \\
\hline & 12 & 1.5 & TD & 25 & $>1000$ \\
\hline & 18 & 1.5 & TD & 25 & $>1000$ \\
\hline \multirow[t]{4}{*}{$21 / 12 / 2016$} & 0 & 1.5 & TD & 25 & $>1000$ \\
\hline & 6 & 2.0 & TD & 30 & 1000 \\
\hline & 12 & 2.5 & TS & 35 & 997 \\
\hline & 18 & 3 & TS & 45 & 991 \\
\hline \multirow[t]{4}{*}{$22 / 12 / 2016$} & 0 & 3 & TS & 45 & 991 \\
\hline & 6 & 3 & TS & 45 & 991 \\
\hline & 12 & 3.5 & TS & 55 & 984 \\
\hline & 18 & 3.5 & TS & 55 & 984 \\
\hline \multirow[t]{4}{*}{$23 / 12 / 2016$} & 0 & 3.5 & TS & 55 & 984 \\
\hline & 6 & 4 & TC Kategori 1 & 65 & 976 \\
\hline & 12 & 4.5 & TC Kategori $1-2$ & 77 & 966 \\
\hline & 18 & 5 & TC Kategori 2-3 & 90 & 954 \\
\hline \multirow[t]{4}{*}{$24 / 12 / 2016$} & 0 & 5.5 & TC Kategori 3 & 102 & 941 \\
\hline & 6 & 6 & TC Kategori 4 & 115 & 927 \\
\hline & 12 & 6.5 & TC Kategori 4 & 127 & 914 \\
\hline & 18 & 6.5 & TC Kategori 4 & 127 & 914 \\
\hline \multirow[t]{4}{*}{$25 / 12 / 2016$} & 0 & 7 & TC Kategori 5 & 140 & 898 \\
\hline & 6 & 6 & TC Kategori 4 & 115 & 927 \\
\hline & 12 & 6 & TC Kategori 4 & 115 & 927 \\
\hline & 18 & 5 & TC Kategori 2-3 & 90 & 954 \\
\hline \multirow[t]{4}{*}{$26 / 12 / 2016$} & 0 & 4 & TC Kategori 1 & 65 & 976 \\
\hline & 6 & 3.5 & TS & 55 & 984 \\
\hline & 12 & 3.5 & TS & 55 & 984 \\
\hline & 18 & 3.5 & TS & 55 & 984 \\
\hline \multirow[t]{4}{*}{$27 / 12 / 2016$} & 0 & 3 & TS & 45 & 991 \\
\hline & 6 & 2.5 & TS & 35 & 997 \\
\hline & 12 & 1.5 & TD & 25 & $>1000$ \\
\hline & 18 & 1 & TD & 25 & $\$ 1000$ \\
\hline
\end{tabular}

\section{KESIMPULAN}

Siklon tropis Nock-Ten yang terbentuk di Samudera Pasifik Barat Daya dapat dipantau pertumbuhan, perkembangan, dan pergerakannya menggunakan data satelit Himawari kanal IR1 yang diperoleh dari basis data satelit Japan Meteorological Agency (JMA) dan basis data satelit BMKG dari tanggal 20 - 28 Desember 2016. Masa hidup siklon tropis Nock-Ten adalah delapan hari, terbentuk di Samudera Pasifik barat daya, bergerak menuju ke arah barat laut, melintasi daratan Filipina pada 25-26 Desember 2016 dan punah di Laut Cina Selatan yang bersuhu dingin.

Energi siklon tropis Nock-Ten diperoleh dari lautan Pasifik yang hangat sehingga mulai melemah ketika memasuki wilayah daratan Filipina dan punah ketika kehilangan sumber uap air hangat. Penelitian ini menggunakan dua metode yaitu analisis indeks konvektif dan analisis pengamatan visual teknik Dvorak.

Data indeks konvektif dari tanggal $20-27$ Desember 2016 menunjukkan bahwa terdapat sistem konveksi yang sangat kuat di area terjadinya siklon tropis Nock-Ten dengan nilai indeks di atas 50. Nilai indeks konvektif di dalam sistem siklon Tropis Nock-Ten berkisar antara 49.9 hingga 74.4 yang mengindikasikan adanya arus konveksi yang kuat dan dalam (deep convection) sehingga mampu menghasilkan sistem awan konvektif yang masif. Selain pertumbuhan dan pergerakan siklon tropis Nock-Ten dapat diketahui, intensitas dari siklon tersebut juga dapat diketahui menggunakan pengamatan visual berbasis teknik Dvorak. Dari analisis Dvorak dapat diketahui bahwa intensitas maksimum dari siklon tropis Nock-Ten adalah Tnumber yang mencapai angka 7.0 pada 25 Desember 2016 pukul 00.00 UTC. Dengan menggunakan tabel Dvorak T-Number, dapat diketahui bahwa pada saat T-Number bernilai 7.0 maka super taifun Nock-Ten memiliki prakiraan nilai tekanan udara minimum di pusat siklonnya mencapai $898 \mathrm{mb}$ dengan prakiraan laju angin maksimum hingga 140 knots, ekuivalen dengan siklon tropis kategori 5 pada skala SaffirSimpson.

\section{DAFTAR PUSTAKA}

Dvorak, V. F., 1975. Tropical Cyclone Intensity Analysis and Forecasting from Satellite Imagery. Monthly Weather Review, Vol. 103, hlm 420-430.

Dvorak, V. F., 1984. Tropical Cyclone Intensity Analysis Using Satellite Data. NOAA Technical Report NESDIS 11, 47 pp.

Emanuel, K., 1988. Toward A General Theory of Hurricanes. American Scientist, Vol. 76, hlm 370-379.

Emanuel, K., 2003. Tropical Cyclones. Annual Review of Earth Planetary Sciences, Vol. 31, hlm 75-104. 
Gray, W. M., 1997. Hurricanes: their formation, structure and likely role in the tropical circulation. Meteorology Over Tropical Oceans, D. B. Shaw, Ed., pp. 155-218, Royal Meteorological Society, Bracknell, Berkshire.

Gray, W. M., 1998. The Formation of Tropical Cyclones. Meteorology and Atmospheric Physics, Vol. 67, hlm 37-69.

Ismail, P., and E.L. Siadari, 2017. Atmospheric Conditions Analysis of the Heavy Rain Phenomenon in Biak (case study 4-5 December 2014). Journal of Phyics: Conf. Ser., Vol. 795012015.

Krismianto, 2015. Analisis Pertumbuhan, Pergerakan, dan Intensitas Siklon Tropis Marcia Berbasis Data Satelit MTSAT. Berita Dirgantara, Vol. 16 No. 1, hlm 37-45.

Liu, C. C., T. Y. Shyu, T. H. Lin, and C. Y. Liu, 2015. Satellite-derived normalized difference convection index. Journal of Applied Remote Sensing, Vol. 9, 096074, hlm 1-18.

Mustika, A., 2008. Karakteristik Siklon Tropis Sekitar Indonesia, Skripsi, Institut Pertanian Bogor, Bogor.

Olander T. L., and C. S. Velden, 2007. The advanced Dvorak technique: continued development of an objective scheme to estimate tropical cyclone intensity using geostationary infrared satellite imagery. Weather Forecast, Vol. 22, hlm 287-298.

Tjasyono, B., 1999. The Impact of Tropical Storms on the Weather over Indonesian. Conference Proceedings. Weather Modification Technical Service Unit Agency for Assessment and Application of Technology, Jakarta.

Tjasyono, B., 2000. Pengantar Geosains, Penerbit ITB, Bandung. 
